\title{
Factors That Affect The Nonpayment Of Municipal Services In Madibeng, Mamelodi And Soshanguve Townships Of South Africa
}

\author{
Zeleke Worku, Tshwane University of Technology, South Africa
}

\begin{abstract}
The study was conducted in Madibeng, Mamelodi and Soshanguve townships of South Africa in order to assess and evaluate the main reasons for the non-payment of municipal services by members of the community. The study was conducted based on a stratified random sample of size 428 households. Statistical data analyses were performed by using methods such as ordered logistic regression analysis and Bayesian analyses. The results showed that $22 \%$ of households in Madibeng, 54\% of households in Mamelodi and 78\% of households in Soshanguve were willing to pay for municipal services that were provided to them by their local municipalities. Reluctance to pay for municipal services was significantly influenced by employment status, level of formal education and race group.
\end{abstract}

Keywords: Madibeng, Mamelodi, Soshanguve, Non-Payment of Municipal Services, Ordered Logistic Regression

\section{INTRODUCTION AND BACKGROUND TO STUDY}

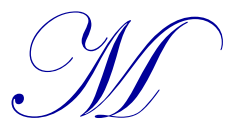

adibeng is a township located in the North West Province of South Africa. Mamelodi and Soshanguve are townships that are located around Pretoria. All three townships are characterized by protests over poor municipal service delivery, a deeply entrenched culture of nonpayment for municipal services, poor infrastructural development, unemployment, and poor access to basic health and educational services. More than half of all newly established business enterprises in the three townships fail in their first year of operation (Khale, 2015). The Local Municipality of Madibeng is a local municipality in Bojanala Platinum District Municipality, North West Province, South Africa. The seat of local municipality is Brits. The popular tourist area of Hartebeespoort is also located in the municipality. According to Statistics South Africa (2012), the population size of Madibeng is about 477, 381. The total area of Madibeng Municipality is about 3, 839 square $\mathrm{km}$. The majority $(89.5 \%)$ of the population is black. The percentages of whites, coloureds and Indians are about $9 \%, 1 \%$ and $0.5 \%$ respectively. The predominant languages spoken at Madibeng are Tshwana (44\%), Tsonga (11\%), Afrikaans (10\%), Northern Sotho (8\%) and English (25\%). The population size of Mamelodi is about 334, 577. The size of Mamelodi Township is about 45.19 square $\mathrm{km}$. The percentage of blacks in Mamelodi is about $99 \%$. The percentages of whites, coloureds and Indians are about $0.4 \%, 0.4 \%$ and $0.2 \%$ respectively. The most commonly spoken languages at Mamelodi Township are Northern Sotho (43\%), Zulu (13\%), Tsonga (11\%), Ndebele (9\%), Afrikaans (14\%) and English (10\%). The population size of Soshanguve Township is about 403,162. The size of Soshanguve Township is 126.77 square $\mathrm{km}$. The percentage of blacks at Soshanguve is about $99.2 \%$. The percentages of whites, coloureds and Indians are about $0.1 \%, 0.3 \%$ and $0.1 \%$ respectively. The most commonly spoken languages are Northern Sotho (29\%), Tswana (17\%), Tsonga (15\%), Zulu (14\%), Afrikaans (14\%) and English (12\%).

Studies conducted by Seeletse (2012), Edoho (2015), Pooe, Worku and Van Rooyen (2016) and Khale (2015) have shown that the three townships have experienced numerous protests over poor municipal service delivery since 1998 , and that the quality of municipal services is often undermined by the nonpayment of municipal services. The aim of the study was to assess the impact of non-payment of municipal services on the quality of municipal service 
delivery. According to Khale (2015), the culture of non-payment of municipal services originates from the liberation struggle against apartheid, where municipal rates were deliberately not paid. All three townships often fail to provide adequate municipal services due to lack of resources such as budget, trained manpower and poor infrastructure. The capacity of the townships to provide satisfactory municipal services has declined due to loss of revenue and lack of willingness to pay for municipal services (Khale, 2015). According to Pooe, Worku and Van Rooyen (2016), the failure of local municipalities in developing South African townships and municipalities to collect revenues that are owed to them has significantly undermined their capacity to maintain the quality of municipal services and the existing municipal infrastructure. According to Edoho (2015) and Brownson (2014), the failure of developing municipalities and townships in South Africa to attract viable business enterprises and create employment opportunities is associated with their failure to provide satisfactory municipal services to operators of small business enterprises. Henrekson (2014) and Marivate (2014) have reported that the failure of developing municipalities to provide adequate municipal services is related to their failure to adhere to the basic principles of good corporate governance such as accountability, transparency and objectivity. Seeletse (2012) and Asah, Fatoki and Rungani (2015) have reported that failure to adhere to the Public Finance Management Act is a common cause of underperformance and poor municipal service delivery in South African townships.

Studies conducted by Khale \& Worku (2013), Khale \& Worku (2015), Worku (2015) and Pooe, Worku \& Van Rooyen (2016) have shown that the quality of municipal service delivery in Madibeng, Mamelodi and Soshanguve townships is often undermined by key obstacles such as lack of specialized skills, failure to adhere to the fundamental principles of good governance, and the absence of a comprehensive performance monitoring and evaluation system for assessing the quality of municipal service delivery. The study was conducted against the background of lack of studies in which the quality and reliability of municipal services that are routinely provided to residents. The aim of the study was to fill the gap by conducting an empirical study designed for identifying and quantifying key predictors of quality municipal service delivery. The Municipal Systems Act of 2000 (Act number 32 of 2000) clearly stipulates norms and standards of municipal services for all South African municipalities and local governments (South African Government Communication and Information System, 2000). The Act states that municipalities are required by law to render efficient, affordable and dependable municipal services to all residents, businesses and stakeholders. The Act also requires all municipalities to develop feasible plans of actions that could be used at times of emergencies and disasters.

Khale (2015) has shown that the key challenge to sustained growth and development in developing municipalities and townships is the failure of municipalities to enforce municipal bylaws, lack of specialized skills, failure to assess and evaluate the productivity of municipal employees. Developing municipalities and townships are characterized by protests over poor municipal service delivery, the absence of performance monitoring and evaluation systems, lack of technical and managerial skills, poor service delivery, the abuse and mismanagement of scarce municipal resources, damage to property and infrastructure and financial mismanagement (Diedericks \& Joubert 2006; Phago, 2009; Marivate, 2014; Khale, 2015). The report issued by the South African Auditor-General (2016) for the financial year 2014/2015 indicates that all three townships experience difficulties such as inability to keep up with the maintenance of public roads, street lights, the supply of water, the removal, disposal and management of municipal solid waste, and problems related to sanitation and the general environment. Municipal employees lack specialized skills in the management of public finance (Horn, 2010; Snyman \& Vorster, 2011; Aigbavboa \& Thwala, 2013).

\section{OBJECTIVE OF STUDY}

The overall objective of study was to assess and evaluate the key causes of non-payment of municipal services among residents and ratepayers of Madibeng, Mamelodi and Soshanguve townships. The study had the following specific objectives:

1. To estimate the percentage of residents of Madibeng, Mamelodi and Soshanguve townships who pay for municipal services that are provided to them on a regular basis;

2. To identify key factors that are responsible for the non-payment of municipal servicers among residents and ratepayers of Madibeng, Mamelodi and Soshanguve townships; and 
3. To identify suitable and feasible remedial actions that could be taken in order to motivate and encourage residents and ratepayers living and conducting business at Madibeng, Mamelodi and Soshanguve townships to pay for municipal services.

\section{LITERATURE REVIEW}

According to Municipal IQ Hotspots Monitor (2016), there were 70 protests over poor municipal service delivery in South African local municipalities. Most of the protests have been in townships such as Madibeng, Mamelodi and Soshanguve. The figures for 2012, 2013, 2014 and 2015 were 173, 155, 191 and 164 respectively. A number of economists and researchers have shown that the number, scale, magnitude and severity of protests over municipal service delivery were significantly associated with socioeconomic factors such as abject poverty, lack of employment opportunities, and lack of basic access to health and educational services. Between 2008 and 2009, there were about 100 municipal service delivery protests in various South African municipalities (Phago, 2009; Horn, 2010; Snyman \& Vorster, 2011; Aigbavboa \& Thwala, 2013). The protests were a result of poor or inadequate municipal services. According to Aguinis \& Kraiger (2009), Aigbavboa \& Thwala (2013) and Alexander (2010), the quality of municipal service delivery must be monitored and evaluated routinely as a means of ensuring the delivery of satisfactory municipal services such as water, lights, road repairs and waste removal. A study conducted by Palvalin, Sillanpaa, Pekkola and Ukko (2012: 43-52) shows that failure to monitor and evaluate routine municipal services that are provided to the general public has potential for undermining the capacities of Madibeng, Mamelodi and Soshanguve townships to utilize their resources optimally. The study aims to identify and quantify key predictors of nonpayment of municipal services at the three townships. No such study has been conducted until now, and the study aims to fill the gap in the relevant literature by conducting an empirical study that would enable the three townships to assess and evaluate the quality of services provided to residents with a view to improve the quality of municipal services provided to residents and ratepayers. There is a need to implement the revenue enhance strategy to commence with billing of consumers in rural areas where high level of services is being provided as well as ensuring that there is affiliated maintenance and support to sustain the water services provision. The study has the potential for identifying and quantifying factors that affect the non-payment of municipal services in the three townships.

Act number 56 of 2003 (The Municipal Management Act (MFMA) of 2003) requires the three townships to provide satisfactory municipal services to all its residents. The MFMA requires the three townships to actively encourage residents and ratepayers in the three townships to provide input to budgeting processes and the Integrated Development Programme (IDP) that has been adopted by the three townships. According to Benjamin, Andreas and Ramon (2012: 1627-1644), the failure of developing municipalities to produce and implement integrated development plans is a key obstacle to sound financial management. The authors have shown that most developing municipalities and townships fail to adhere to Act number 56 of 2003 (The Municipal Management Act (MFMA) of 2003).

Madibeng, Mamelodi and Soshanguve townships are all developing municipalities that have not been adequately studied with regards to factors that affect the quality of municipal service delivery. Not many researchers have conducted empirical studies with a view to assess the reasons for non-payment of municipal services. This study aims to fill the gap in this area by conducting a well-planned scientific study by collecting fresh data from residents and ratepayers. The study attempts to gain an understanding of the current perceptions on the quality of services delivered by the municipality with a particular focus on the underlying causes of non-payment of municipal services. In local municipalities such as Attridgeville, Mamelodi, Alexandra, Soshanguve, Mabopane and Winterveld, studies have shown that the quality of municipal services has been undermined due to a culture of non-payment of municipal services (Pooe, Worku \& Van Rooyen, 2016). The study has the potential for making a meaningful contribution to the literature by identifying the root causes of non-payment of municipal services. It also has the potential to identify factors that affect the degree of satisfaction of residents and ratepayers on the quality of municipal services that are delivered to them by employees of municipalities operating in the three townships.

Studies conducted by Khale and Worku (2013) and Pooe, Worku \& Van Rooyen (2016) have shown that the nonpayment of municipal services has severe consequences on the development and growth of developing municipalities in all regions of South Africa. The authors have pointed out that awareness campaigns are necessary 
as a means of encouraging and motivating ratepayers and ordinary residents to pay for municipal services promptly. Developing local municipalities often lack the financial resources that are necessary for maintaining infrastructure, public roads and buildings and paying the cost of human resources. They solely rely on the payment of municipal services. Often, payments are not made promptly and fully. As a result, most developing municipalities fail to deliver adequate municipal services. This often results in failure to attract big and profitable businesses as a means of growing the local economy.

According to Henrekson (2014), developing municipalities that do not attract businesses often fail to generate enough revenue for the efficient delivery of essential services. Kovacevic (2012) has shown that local municipalities that have promoted affirmative action have failed to deliver efficient municipal services. The author has pointed out that the private sector must be allowed and encouraged to play a central role in attracting businesses and growing the local economy. Linna, Pekkola, Ukko and Melkas (2010) have shown that public sector organizations such as developing municipalities must be encouraged and motivated to work with the private sector in order to grow the local economies of rural and semi-rural regions of South Africa. The authors have argued that public-private partnerships must be actively encouraged and promoted in all developing municipalities in order to achieve a reasonable rate of sustained economic growth.

According to Dawson (2010: 519-533), norms and standards in service delivery must be clearly defined and measurable in order to assess service quality and degree of success. The success achieved by an organization in service delivery cannot be quantified and measured if there is no service quality assurance. Elected officials often claim that objectives have been met, but they fail to provide tangible evidence to substantiate their claims. Such a failure undermines the credibility of local municipalities in the eyes of residents, rate payers and stakeholders. The remedial action in this regard is to use quality control mechanisms and verification of claims made by elected officials (Gerdin \& Greve, 2004).

According to the Municipal IQ Hotspot Monitor (2016), 111 service delivery protests were observed in the year 2010 by South Africans due to poor municipal services. In the year 2012, only 5\% of 283 local municipalities in South Africa have received a clean financial audit for the financial year 2010/2011. The key reasons of protests have been inability to respond to queries, failure to account for budgets and finances, failure to maintain municipal services and infrastructure, lack of skills in financial mismanagement and keeping records and failure to use performance monitoring mechanisms for assessing the quality of municipal services. Pooe, Worku and Van Rooyen (2016) have suggested that workplace training programmes should be used by local municipalities for ensuring the quality of municipal services. According to the South African Auditor-General (2016), more than half of all officials responsible for handling the finances of municipalities lack the minimum competencies and skills required for performing their jobs. Perego \& Hartmann (2009: 397-428) and Peng, Pike \& Roos (2007: 538-556) have developed performance monitoring and evaluation indicators that are suitable for assessing the quality of municipal service delivery in developing municipalities and townships. According to the authors, a special emphasis must be placed on the acquisition of specialized skills as a means of ensuring adequate municipal service delivery to customers.

Studies conducted by Khale \& Worku (2013), Khale \& Worku (2015), Worku (2015) and Pooe, Worku \& Van Rooyen (2016) have shown that the quality of municipal service delivery in townships such as Madibeng, Mamelodi and Soshanguve is often undermined by key obstacles such as lack of specialized skills, failure to adhere to the fundamental principles of good governance, and the absence of a comprehensive performance monitoring and evaluation system for assessing the quality of municipal service delivery. The Municipal Systems Act of 2000 (Act number 32 of 2000) clearly stipulates norms and standards of municipal services for all South African municipalities and local governments (South African Government Communication and Information System, 2000). The Act states that municipalities are required by law to render efficient, affordable and dependable municipal services to all residents, businesses and stakeholders. The Act also requires all municipalities to develop feasible plans of actions that could be used at times of emergencies and disasters. According to Brinkerhoff and Brinkerhoff (2015: 222-237), good municipal leaders are characterized by respect for the basic tenets of good governance (accountability, transparency and objectivity). The authors have recommended the use of performance monitoring and evaluation mechanisms, workplace training programmes, the provision of incentives to top performers and the strict enforcement of municipal bylaws. 


\section{METHODS AND MATERIALS OF STUDY}

The study was conducted based on a stratified random sample of size 428 households in Madibeng, Mamemlodi and Soshanguve townships. The population sizes of Madibeng (477, 381), Mamemlodi (334, 577) and Soshanguve (403, 162) townships were estimated based on a census conducted by Statistics South Africa (2012) in the year 2011. Stratification was done by township. Data was collected on socioeconomic factors that are known to undermine the quality of municipal service delivery. At each household, data was collected from the head of the household. Data collection was done by using a structured, pre-tested and validated questionnaire of study from each of the 428 households in the three townships. A random sample of size 167 households ( $39 \%$ of the total sample size of study) was drawn from Madibeng. A random sample of size 120 households was drawn from Mamelodi (28\% of the total sample size of study). A random sample of size 141 (33\% of the total sample size of study) was drawn from Soshanguve. The key aim of study was to identify and quantify key predictors of nonpayment of municipal services. The degree of satisfaction of households on the quality of municipal services provided to them was assessed by using a 5-point ordinal scale. Cross-tab analyses (Hair, Black, Rabin \& Anderson, 2010), ordered logistic regression analysis (Kleinbaum, Kupper, Nizam \& Rosenberg, 2013) and Bayesian analysis (Browne \& Goldstein, 2010) were used for performing data analyses. The statistical package STATA version 15 (STATA Corporation, 2017) was used for data analyses.

\section{RESULTS OF STUDY}

Table 1 shows percentages for the general characteristics of the 120 respondents who took part in the study. It can be seen from the table that the percentage of respondents who were willing to pay for municipal services was equal to $60.83 \%$. The percentage of respondents who were not willing to pay for municipal services was equal to $39.17 \%$. The percentages of respondents at Madibeng, Mamelodi and Soshanguve whose ages were between 20 and 36 years were $43 \%, 48 \%$ and $47 \%$ respectively. The percentages of male respondents at Madibeng, Mamelodi and Soshanguve were $59 \%, 57 \%$ and $56 \%$ respectively. The percentages of black respondents at Madibeng, Mamelodi and Soshanguve were equal to $84 \%, 85 \%$ and $88 \%$ respectively. The percentages of respondents at Madibeng, Mamelodi and Soshanguve whose highest levels of education were matric level or less were $7 \%, 9 \%$ and $8 \%$ respectively. The percentages of respondents at Madibeng, Mamelodi and Soshanguve whose monthly average incomes were R7, 001 or more were $28 \%, 26 \%$ and $46 \%$ respectively.

The percentages of respondents at Madibeng, Mamelodi and Soshanguve who were employed full time were 12\%, $11 \%$ and $26 \%$ respectively. 
Table 1. General characteristics of respondents $(n=428)$

\begin{tabular}{|c|c|c|c|}
\hline Characteristics of respondents & Madibeng (n1=167) & Mamelodi (n2=120) & Soshanguve (n3=141) \\
\hline \multirow{2}{*}{$\begin{array}{l}\text { Willingness to pay for municipal } \\
\text { services }\end{array}$} & Yes: $22 \%$ & Yes: $54 \%$ & Yes: $78 \%$ \\
\hline & No: $78 \%$ & No: $46 \%$ & No: $22 \%$ \\
\hline \multirow{4}{*}{ Age categories of respondents in years } & 20 to $36: 43 \%$ & 20 to $36: 48 \%$ & 20 to $36: 47 \%$ \\
\hline & 37 to $45: 25 \%$ & 37 to $45: 27 \%$ & 37 to $45: 26 \%$ \\
\hline & 46 to $55: 17 \%$ & 46 to $55: 18 \%$ & 46 to $55: 19 \%$ \\
\hline & 56 or more: $15 \%$ & 56 or more: $7 \%$ & 56 or more: $8 \%$ \\
\hline \multirow{2}{*}{ Gender of respondents } & Male: $59 \%$ & Male: $57 \%$ & Male: $56 \%$ \\
\hline & Female: $41 \%$ & Female: $43 \%$ & Female: $44 \%$ \\
\hline \multirow{4}{*}{ Racial category of respondents } & Black: $84 \%$ & Black: $85 \%$ & Black: $88 \%$ \\
\hline & White: $11 \%$ & White: $10 \%$ & White: $8 \%$ \\
\hline & Coloured: $3 \%$ & Coloured: $4 \%$ & Coloured: $2 \%$ \\
\hline & Indian: $2 \%$ & Indian: $1 \%$ & Indian: $2 \%$ \\
\hline \multirow{2}{*}{ Gender of respondent } & Male: $78 \%$ & Male: $79 \%$ & Male: $81 \%$ \\
\hline & Female: $22 \%$ & Female: $21 \%$ & Female: $19 \%$ \\
\hline \multirow[t]{5}{*}{ Highest level of education } & Matric or less: $7 \%$ & Matric or less: $9 \%$ & Matric or less: $8 \%$ \\
\hline & Certificate: $30 \%$ & Certificate: $29 \%$ & Certificate: $31 \%$ \\
\hline & Diploma: $31 \%$ & Diploma: $30 \%$ & Diploma: $26 \%$ \\
\hline & Bachelor's degree: $24 \%$ & Bachelor's degree: $25 \%$ & Bachelor's degree: $23 \%$ \\
\hline & Master's or more: $8 \%$ & Master's or more: $7 \%$ & Master's or more: $12 \%$ \\
\hline \multirow{5}{*}{ Highest level of education } & Matric or less: $7 \%$ & Matric or less: $9 \%$ & Matric or less: $8 \%$ \\
\hline & Certificate: $30 \%$ & Certificate: $29 \%$ & Certificate: $31 \%$ \\
\hline & Diploma: $31 \%$ & Diploma: $30 \%$ & Diploma: $26 \%$ \\
\hline & Bachelor's degree: $24 \%$ & Bachelor's degree: $25 \%$ & Bachelor's degree: $23 \%$ \\
\hline & Master's or more: $8 \%$ & Master's or more: $7 \%$ & Master's or more: $12 \%$ \\
\hline \multirow{3}{*}{$\begin{array}{l}\text { Average monthly income of household } \\
\text { in Rand }\end{array}$} & R3, 500 or less: $39 \%$ & R3, 500 or less: $38 \%$ & R3, 500 or less: $21 \%$ \\
\hline & $\mathrm{R} 3,501$ to $\mathrm{R} 7,000: 33 \%$ & $\mathrm{R} 3,501$ to $\mathrm{R} 7,000: 36 \%$ & $\mathrm{R} 3,501$ to $\mathrm{R} 7,000: 31 \%$ \\
\hline & R7, 001 or more: $28 \%$ & R7, 001 or more: $26 \%$ & $\mathrm{R} 7,001$ or more: $48 \%$ \\
\hline \multirow{4}{*}{$\begin{array}{l}\text { Employment status of head of } \\
\text { household }\end{array}$} & Full time employed: $12 \%$ & Full time employed: $11 \%$ & Full time employed: $26 \%$ \\
\hline & Part-time employed: $23 \%$ & Part-time employed: $24 \%$ & Part-time employed:37\% \\
\hline & Self-employed: $38 \%$ & Self-employed: $39 \%$ & Self-employed: $24 \%$ \\
\hline & Not employed: $27 \%$ & Not employed: $26 \%$ & Not employed: $13 \%$ \\
\hline
\end{tabular}

Table 2 shows figures for the percentages of respondents who pay for municipal services. The percentages of respondents at Madibeng, Mamelodi and Soshanguve who regularly pay for electricity services were equal to $18 \%$, $48 \%$ and $67 \%$ respectively. The percentages of respondents at Madibeng, Mamelodi and Soshanguve who regularly pay for water services were equal to $19 \%, 51 \%$ and $64 \%$ respectively. The percentages of respondents at Madibeng, Mamelodi and Soshanguve who regularly pay for waste removal and sanitation services were equal to $17 \%$, 52\% and $63 \%$ respectively. The percentages of respondents at Madibeng, Mamelodi and Soshanguve who paid up their bills monthly were equal to $18 \%, 43 \%$ and $64 \%$ respectively. The percentages of respondents at Madibeng, Mamelodi and Soshanguve who preferred to receive their municipal statements through their residential addresses were equal to $78 \%, 81 \%$ and $83 \%$ respectively. The percentages of respondents at Madibeng, Mamelodi and Soshanguve who preferred to pay their municipal bills at municipal offices were equal to $76 \%, 71 \%$ and $51 \%$ respectively. 
Table 2. Frequency of payment of municipal services $(n=428)$

\begin{tabular}{|c|c|c|c|}
\hline Characteristics of respondents & Madibeng $(\mathrm{n} 1=167)$ & Mamelodi (n2=120) & Soshanguve (n3=141) \\
\hline \multirow{3}{*}{ Payment of electricity services } & Yes: $18 \%$ & Yes: $48 \%$ & Yes: $67 \%$ \\
\hline & No: $78 \%$ & No: $46 \%$ & No: $22 \%$ \\
\hline & Sometimes: $4 \%$ & Sometimes: $6 \%$ & Sometimes: $11 \%$ \\
\hline \multirow{3}{*}{ Payment of water services } & Yes: $19 \%$ & Yes: $51 \%$ & Yes: $64 \%$ \\
\hline & No: $77 \%$ & No: $42 \%$ & No: $21 \%$ \\
\hline & Sometimes: $4 \%$ & Sometimes: $7 \%$ & Sometimes: $13 \%$ \\
\hline \multirow{3}{*}{$\begin{array}{l}\text { Payment of waste removal and } \\
\text { sanitation services }\end{array}$} & Yes: $17 \%$ & Yes: $52 \%$ & Yes: $63 \%$ \\
\hline & No: $80 \%$ & No: $43 \%$ & No: $19 \%$ \\
\hline & Sometimes: $3 \%$ & Sometimes: $5 \%$ & Sometimes: $18 \%$ \\
\hline \multirow{5}{*}{$\begin{array}{l}\text { Preferred frequency of payment of } \\
\text { municipal services }\end{array}$} & Monthly: $18 \%$ & Monthly: $43 \%$ & Monthly: $64 \%$ \\
\hline & Quarterly: 2\% & Quarterly: 4\% & Quarterly: 8\% \\
\hline & Bi-annually: $1 \%$ & Bi-annually: 3\% & Bi-annually: 4\% \\
\hline & Annually: $1 \%$ & Annually: $4 \%$ & Annually: $2 \%$ \\
\hline & Not applicable: $78 \%$ & Not applicable: $46 \%$ & Not applicable: $22 \%$ \\
\hline \multirow{3}{*}{$\begin{array}{l}\text { Preferred method of receiving } \\
\text { statements for services }\end{array}$} & Residential address: $78 \%$ & Residential address: $81 \%$ & Residential address: $83 \%$ \\
\hline & $\begin{array}{l}\text { Postal address: } 14 \% \\
\text { E-Mail: } 5 \%\end{array}$ & $\begin{array}{l}\text { Postal address: } 17 \% \\
\text { E-Mail: } 4 \%\end{array}$ & $\begin{array}{l}\text { Postal address: } 15 \% \\
\text { E-Mail: } 6 \%\end{array}$ \\
\hline & Personal collection: $3 \%$ & Personal collection: $4 \%$ & Personal collection: $2 \%$ \\
\hline \multirow{6}{*}{ Preferred site of payment for services } & Municipal office: $76 \%$ & Municipal office: $71 \%$ & Municipal office: $51 \%$ \\
\hline & Post office: $17 \%$ & Post office: $18 \%$ & Post office: $31 \%$ \\
\hline & Supermarket: $3 \%$ & Supermarket: $4 \%$ & Supermarket: $8 \%$ \\
\hline & Online: $1 \%$ & Online: $2 \%$ & Online: $4 \%$ \\
\hline & Bank: $2 \%$ & Bank: $3 \%$ & Bank: $4 \%$ \\
\hline & Others: $1 \%$ & Others: $2 \%$ & Others: $2 \%$ \\
\hline
\end{tabular}

Table 3 shows figures for the main reasons for the nonpayment of municipal services. The percentages of residents who pay monthly fees of R701 or more at Madibeng, Mamelodi and Soshanguve were equal to $16 \%, 34 \%$ and $39 \%$ respectively. The percentages of respondents at Madibeng, Mamelodi and Soshanguve who felt that municipal fees were quite affordable were equal to $6 \%, 13 \%$ and $33 \%$ respectively. The percentages of respondents at Madibeng, Mamelodi and Soshanguve who were unable to pay for municipal services due to dissatisfaction with the quality of services were $22 \%, 43 \%$ and $66 \%$ respectively. The percentages of respondents at Madibeng, Mamelodi and Soshanguve who felt that the Government should pay for municipal services were equal to $55 \%, 34 \%$ and $15 \%$ respectively. 
Table 3. Reasons for non-payment of municipal services $(n=428)$

\begin{tabular}{|c|c|c|c|}
\hline $\begin{array}{l}\text { Characteristics of } \\
\text { respondents }\end{array}$ & Madibeng (n1=167) & Mamelodi (n2=120) & Soshanguve $(n 3=141)$ \\
\hline \multirow{4}{*}{$\begin{array}{l}\text { Average amount of } \\
\text { money paid for municipal } \\
\text { services per month in } \\
\text { Rand }\end{array}$} & R300 or less: $42 \%$ & R300 or less: $24 \%$ & R300 or less: $16 \%$ \\
\hline & R301 to R700: $29 \%$ & $\mathrm{R} 301$ to $\mathrm{R} 700: 36 \%$ & R301 to R700: $41 \%$ \\
\hline & R701 or more: $16 \%$ & R701 or more: $34 \%$ & R701 or more: $39 \%$ \\
\hline & Not applicable: $13 \%$ & Not applicable: $6 \%$ & Not applicable: $4 \%$ \\
\hline \multirow{4}{*}{$\begin{array}{l}\text { Affordability of } \\
\text { municipal services }\end{array}$} & Quite affordable: $6 \%$ & Quite affordable: $13 \%$ & Quite affordable: $33 \%$ \\
\hline & Moderately affordable: $7 \%$ & Moderately affordable: $19 \%$ & Moderately affordable: $37 \%$ \\
\hline & Not affordable: $9 \%$ & Not affordable: $22 \%$ & Not affordable: $8 \%$ \\
\hline & Not applicable: $78 \%$ & Not applicable: $46 \%$ & Not applicable: $22 \%$ \\
\hline \multirow{3}{*}{$\begin{array}{l}\text { Reason for the non- } \\
\text { payment of municipal } \\
\text { services }\end{array}$} & No money: $72 \%$ & No money: $48 \%$ & No money: $21 \%$ \\
\hline & Not happy with services: $22 \%$ & Not happy with services: $43 \%$ & Not happy with services: $66 \%$ \\
\hline & Not applicable or others: $6 \%$ & Not applicable or others: $9 \%$ & Not applicable or others: $13 \%$ \\
\hline \multirow{4}{*}{$\begin{array}{l}\text { Who should pay for } \\
\text { municipal services on } \\
\text { behalf of defaulters? }\end{array}$} & Residents: $22 \%$ & Residents: $55 \%$ & Residents: $78 \%$ \\
\hline & The Government: $55 \%$ & The Government: $34 \%$ & The Government: $15 \%$ \\
\hline & NGOs: $14 \%$ & NGOs: $8 \%$ & NGOs: $4 \%$ \\
\hline & Not applicable: $9 \%$ & Not applicable: $3 \%$ & Not applicable: $3 \%$ \\
\hline
\end{tabular}

Table 4 shows percentages for the perception held by respondents about obligations of residents to municipalities. The percentages of residents who strongly believed that there should be negotiations between residents and municipalities about monthly payments for municipal services at Madibeng, Mamelodi and Soshanguve were equal to $41 \%, 39 \%$ and $27 \%$ respectively. The percentages of residents who strongly believed that unpaid fees for municipal services should be written off as a loss at Madibeng, Mamelodi and Soshanguve were equal to $40 \%, 38 \%$ and $26 \%$ respectively. The percentages of residents who believed that fees for municipal services should be paid up by the Government at Madibeng, Mamelodi and Soshanguve were equal to $62 \%, 34 \%$ and $19 \%$ respectively. The percentages of residents who strongly believed that unpaid fees should be recovered from defaulters by legal means at Madibeng, Mamelodi and Soshanguve were equal to $27 \%, 39 \%$ and $41 \%$ respectively. The percentages of residents who strongly believed that there was lack of good governance at Madibeng, Mamelodi and Soshanguve were equal to $48 \%, 34 \%$ and $22 \%$ respectively. 
Table 4. Perceptions about obligations of residents to municipalities $(n=428)$

\begin{tabular}{|c|c|c|c|}
\hline Characteristics of respondents & Madibeng (n1=167) & Mamelodi (n2=120) & Soshanguve (n3=141) \\
\hline \multirow{5}{*}{$\begin{array}{l}\text { Perception on the need for } \\
\text { negotiations with residents about } \\
\text { payment }\end{array}$} & Strongly agree: $41 \%$ & Strongly agree: $39 \%$ & Strongly agree: $27 \%$ \\
\hline & Agree: $22 \%$ & Agree: $23 \%$ & Agree: $11 \%$ \\
\hline & Neutral: $17 \%$ & Neutral: $18 \%$ & Neutral: $49 \%$ \\
\hline & Disagree: $13 \%$ & Disagree: $12 \%$ & Disagree: $9 \%$ \\
\hline & Strongly disagree: $7 \%$ & Strongly disagree: $8 \%$ & Strongly disagree: $4 \%$ \\
\hline \multirow{5}{*}{$\begin{array}{l}\text { Perception on the importance of } \\
\text { payment for municipal services }\end{array}$} & Strongly agree: $20 \%$ & Strongly agree: $26 \%$ & Strongly agree: $37 \%$ \\
\hline & Agree: $10 \%$ & Agree: $13 \%$ & Agree: $16 \%$ \\
\hline & Neutral: $15 \%$ & Neutral: $14 \%$ & Neutral: $13 \%$ \\
\hline & Disagree: $11 \%$ & Disagree: $10 \%$ & Disagree: $8 \%$ \\
\hline & Strongly disagree: $44 \%$ & Strongly disagree: $37 \%$ & Strongly disagree: $26 \%$ \\
\hline \multirow{5}{*}{$\begin{array}{l}\text { Perception on the need to write } \\
\text { off unpaid municipal bills as a } \\
\text { loss }\end{array}$} & Strongly agree: $40 \%$ & Strongly agree: $38 \%$ & Strongly agree: $26 \%$ \\
\hline & Agree: $21 \%$ & Agree: $22 \%$ & Agree: $10 \%$ \\
\hline & Neutral: $19 \%$ & Neutral: $17 \%$ & Neutral: $48 \%$ \\
\hline & Disagree: $12 \%$ & Disagree: $16 \%$ & Disagree: $12 \%$ \\
\hline & Strongly disagree: $8 \%$ & Strongly disagree: $7 \%$ & Strongly disagree: $4 \%$ \\
\hline \multirow{3}{*}{$\begin{array}{l}\text { Perception on who should pay for } \\
\text { municipal services }\end{array}$} & Residents: $21 \%$ & Residents: $52 \%$ & Residents: $74 \%$ \\
\hline & The Government: $62 \%$ & The Government: $34 \%$ & The Government: $19 \%$ \\
\hline & NGOs: $17 \%$ & NGOs: $14 \%$ & NGOs: $7 \%$ \\
\hline \multirow{5}{*}{$\begin{array}{l}\text { Perception on the need to recover } \\
\text { unpaid monies from defaulters by } \\
\text { legal means }\end{array}$} & Strongly agree: $27 \%$ & Strongly agree: $39 \%$ & Strongly agree: $41 \%$ \\
\hline & Agree: $11 \%$ & Agree: $23 \%$ & Agree: $22 \%$ \\
\hline & Neutral: $49 \%$ & Neutral: $18 \%$ & Neutral: $17 \%$ \\
\hline & Disagree: $9 \%$ & Disagree: $12 \%$ & Disagree: $13 \%$ \\
\hline & Strongly disagree: $4 \%$ & Strongly disagree: $8 \%$ & Strongly disagree: $7 \%$ \\
\hline \multirow{5}{*}{$\begin{array}{l}\text { Perception of lack of good } \\
\text { governance }\end{array}$} & Strongly agree: $48 \%$ & Strongly agree: $34 \%$ & Strongly agree: $22 \%$ \\
\hline & Agree: $18 \%$ & Agree: $16 \%$ & Agree: $13 \%$ \\
\hline & Neutral: $11 \%$ & Neutral: $10 \%$ & Neutral: $8 \%$ \\
\hline & Disagree: $16 \%$ & Disagree: $14 \%$ & Disagree: $27 \%$ \\
\hline & Strongly disagree: $7 \%$ & Strongly disagree: $26 \%$ & Strongly disagree: $30 \%$ \\
\hline
\end{tabular}

Pearson's chi-square tests of associations (Hair, Black, Babin and Anderson, 2010) of two-by-two cross-tab analyses were used for assessing the strength of association between the non-payment of municipal services and various socioeconomic characteristics of respondents. Table 6 shows results obtained from the Pearson chi-square test of association (cross-tab analyses). The table shows observed chi-square values and P-values for significant two-bytwo associations between nonpayment of municipal services and 22 socioeconomic characteristics of the respondents who took part in the study. At the 0.05 level of significance, significant associations have P-values that are smaller than 0.05 . 
Table 6. Results obtained from cross-tab analyses $(n=428)$

\begin{tabular}{|l|l|l}
\hline \multicolumn{1}{|c}{ List of 22 variables significantly associated with nonpayment of municipal services } & Chi-square value & \multicolumn{1}{c}{ P-value } \\
\hline Failure of municipal employees to talk to residents about payment of municipal services & 28.9304 & $0.000^{* * *}$ \\
\hline Culture of non-payment of municipal services & 28.7748 & $0.000^{* * *}$ \\
\hline Perception that payment of municipal services is not important & 24.9024 & $0.000^{* * *}$ \\
\hline High cost of municipal services & 20.6585 & $0.000^{* * *}$ \\
\hline Method used for payment of bills & 18.8247 & $0.001^{* *}$ \\
\hline Perception that someone else should pay for municipal services & 17.8213 & $0.000^{* * *}$ \\
\hline Perception that everybody must pay an equal amount & 17.3789 & $0.000^{* * *}$ \\
\hline Not believing in rationale of payment for services & 17.2891 & $0.001^{* *}$ \\
\hline Failure to provide incentives to non-defaulters & 16.7885 & $0.000^{* * *}$ \\
\hline Low household income & 16.5666 & $0.000^{* * *}$ \\
\hline Perception that municipal bills must be written off as a loss & 15.7313 & $0.000^{* * *}$ \\
\hline Frequency of payment for water services & 14.2349 & $0.003^{* *}$ \\
\hline Institution where bills are paid & 13.5194 & $0.009^{* *}$ \\
\hline Perception that regular payment must not be a requirement & 13.2156 & $0.000^{* * *}$ \\
\hline Failure to punish defaulters & 10.7545 & $0.005^{* *}$ \\
\hline Not affording to pay & 10.0960 & $0.018^{* *}$ \\
\hline Reluctance to pay for water services & 9.6429 & $0.008^{* *}$ \\
\hline Failure to take court action on defaulters & 8.3954 & $0.004^{* *}$ \\
\hline Perception that payment of municipal services should be negotiated & 8.2799 & $0.004^{* *}$ \\
\hline High cost of water services & 6.5316 & $0.038^{*}$ \\
\hline Gender & 5.5499 & $0.018^{* *}$ \\
\hline Leniency on defaulters & 4.9024 & $0.027^{*}$ \\
\hline
\end{tabular}

Legend: Significance of association at $* \mathrm{P}<0.05 ; \quad * * \mathrm{P}<0.01 ; \quad$ *** $\mathrm{P}<0.001$

Results shown in Table 6 indicate that non-payment of municipal services was significantly associated with failure of municipal employees to talk to residents about payment of municipal services, culture of non-payment of municipal services, perception that payment of municipal services is not important, high cost of municipal services, method used for payment of bills, perception that someone else should pay for municipal services, perception that everybody must pay an equal amount, not believing in rationale of payment for services, failure to provide incentives to non-defaulters, low household income, perception that municipal bills must be written off as a loss, frequency of payment for water services, institution where bills are paid, perception that regular payment must not be a requirement, failure to punish defaulters, not affording to pay, reluctance to pay for water services, failure to take court action on defaulters, perception that payment of municipal services should be negotiated, high cost of water services, gender and leniency on defaulters, in a decreasing order of strength.

Ordered logistic regression analysis (Kleinbaum, Kupper, Nizam and Rosenberg, 2013) was used in order to identify key predictors of non-payment of municipal services. As a means of simplifying the interpretation of results, regression coefficients estimated from ordered logistic regression analysis were transformed into odds ratios by obtaining the exponential values of estimated regression coefficients and $95 \%$ confidence intervals of regression coefficients. Table 7 shows odds ratios estimated from analysis. Results obtained from ordered logistic regression analysis show that the non-payment of municipal services was significantly influenced by 3 predictor variables. These predictor variables were: failure of municipal employees to talk to residents about payment of municipal services, culture of non-payment of municipal services, and the perception that payment of municipal services was not important, in a decreasing order of strength. Odds ratios were used as a measure of effect. At the $5 \%$ level of significance, significant predictor variables are characterised by odds ratios that differ from 1 significantly, P-values that are smaller than 0.05 , and $95 \%$ confidence intervals that do not contain 1 . Table 7 shows odds ratios estimated from logit analysis. It can be seen from the table that all 3 predictor variables were highly significant at the $5 \%$ level of significance. 
Table 7. Results from ordered logistic regression analysis

\begin{tabular}{l|c|c|c}
\hline \multicolumn{1}{|c|}{ Factors that affect nonpayment of municipal services significantly } & Odds Ratio & P-value & $\mathbf{9 5 \%}$ C. I. \\
\hline $\begin{array}{l}\text { Failure of municipal employees to talk to residents about payment of } \\
\text { municipal services }\end{array}$ & 3.84 & 0.000 & $(2.17,6.69)$ \\
\hline Culture of non-payment of municipal services & 3.44 & 0.000 & $(2.11,6.01)$ \\
\hline Perception that payment of municipal services is not important & 2.53 & 0.000 & $(1.89,4.94)$ \\
\hline
\end{tabular}

The percentage of overall correct classification for this procedure was equal to $82.04 \%$. The P-value obtained from the Hosmer-Lemeshow (2013) goodness-of-fit test was equal to $0.1109>0.05$. This indicates that the fitted logistic regression model is fairly well reliable.

\section{Interpretation of Significant Odds Ratios}

The odds ratio of the variable "Failure of municipal employees to talk to residents about payment of municipal services" is equal to 3.84 . This indicates that a ratepayer who has no visit from an employee of the municipality is 3.84 times as likely to default on payment in comparison with a ratepayer who is visited by an employee of the municipality. The odds ratio of the variable "Culture of nonparent" is equal to 3.44. This indicates that a ratepayer who has a culture of non-payment of municipal services is 3.44 times as likely to default on payment in comparison with a ratepayer who is free from a culture of non-payment of municipal services. The odds ratio of the variable "Perception that payment of municipal services is not important" is equal to 2.53. This indicates that a ratepayer who believes that the payment of municipal services is not important is 2.53 times as likely to default on payment in comparison with a ratepayer who believes that it is important to pay for municipal services.

Table 8 shows regression estimates obtained from Bayesian analysis (Browne \& Goldstein, 2010).

Table 8. Regression coefficients estimated from Bayesian analysis

\begin{tabular}{l|c|c|c}
\hline \multicolumn{1}{|c|}{ Predictor variable } & $\begin{array}{c}\text { Regression } \\
\text { coefficient }\end{array}$ & $\begin{array}{c}\text { 95\% Confidence } \\
\text { Interval }\end{array}$ & P-value \\
\hline $\begin{array}{l}\text { Failure of municipal employees to talk to residents } \\
\text { about payment of municipal services }\end{array}$ & 2.31 & $(1.17,3.74)$ & 0.000 \\
\hline $\begin{array}{l}\text { Culture of non-payment of municipal services } \\
\text { Perception that payment of municipal services is not } \\
\text { important }\end{array}$ & 2.21 & $(1.14,3.53)$ & 0.000 \\
\hline
\end{tabular}

The estimates obtained from Bayesian analysis were fairly similar to estimates obtained from cross-tab analyses and ordered logistic regression analysis.

As part of the study, personal inspection was done at various parts of the municipality. Discussions were held with ordinary residents, municipal employees and officials. Various reasons were provided by the respondents of the study for the non-payment of municipal services by defaulters. Examples of such reasons were lack of awareness campaigns to have residents educated about the merits of paying for municipal services, the wrong perception that the cost of municipal services was unaffordable, the wrong assumption that monies paid for municipal services were not used for the benefit of the municipality, the perception that municipal officials did not care enough about the plight of residents and ratepayers, lack of ownership of the municipality, lack of confidence in the ability of municipal employees and officials to improve the plight of residents and ratepayers, inability to pay for municipal services due to joblessness and lack of steady income and poor motivation.

Pla-Barber and Ghauri (2012: 1007-1010) have shown that local municipalities are required to ensure the delivery of quality municipal services to all residents and ratepayers in order to build trust and self-confidence. The infrastructure needed for the delivery of municipal services needs to be regularly upgraded in order to render adequate services to a growing population. The study by Booysens (2011: 67-78) has shown that the quality of municipal services provided to small businesses in South African townships is grossly inadequate, and that an 
intervention was called for. The author has found that the growth of small businesses in townships was undermined due to lack of effective municipal service delivery in townships. The study conducted by Calvin (2012: 34-35) has shown that the globalized nature of local municipalities requires skills development among elective officials so that they can provide adequate municipal services to potential investors who wish to set up shops and services in townships. Cairns and Sears (2012) has reported that small businesses need infrastructural support from local municipalities in order to provide affordable and efficient services to residents living in townships.

Calvin (2012: 34-35) has shown that the degree to which entrepreneurial activities grow in townships depends on the quality of municipal services. Ratepayers and residents of townships often struggle to set up new businesses due to lack of infrastructure and poor municipal services. Culkin and Mallick (2011: 347-368) have reported that newly established businesses in townships often go out of business due to lack of adequate municipal services such as sanitation, water and lights. Small businesses are essential for creating employment opportunities in townships.

\section{SUMMARY OF KEY FINDINGS}

The study has produced significant findings that have not been reported formally about Sekhukhune District Municipality. The study has attempted to highlight the key causes of non-payment for municipal services by members of the community. The purpose of the study was to identify the root causes of non-payment of municipal services such as electricity, water, sanitation and waste removal services. The design of the study was descriptive and cross-sectional. The sample size of study was equal to 120 households. Statistical data analyses were performed by using methods such as frequency tables, cross-tab analyses, and binary logistic regression analysis. The results showed that $60.83 \%$ of respondents were willing to pay for municipal services that were provided to them by Sekhukhune District Municipality, whereas $39.17 \%$ of respondents were not willing to pay for municipal services provided to them by the municipality. Reluctance to pay for municipal services was significantly associated with failure of municipal employees to talk to residents about payment of municipal services, culture of non-payment of municipal services, perception that payment of municipal services is not important, high cost of municipal services, method used for payment of bills, perception that someone else should pay for municipal services, perception that everybody must pay an equal amount, not believing in rationale of payment for services, failure to provide incentives to non-defaulters, low household income, perception that municipal bills must be written off as a loss, frequency of payment for water services, institution where bills are paid, perception that regular payment must not be a requirement, failure to punish defaulters, not affording to pay, reluctance to pay for water services, failure to take court action on defaulters, perception that payment of municipal services should be negotiated, high cost of water services, gender and leniency on defaulters, in a decreasing order of strength. Results obtained from logit analysis showed that the non-payment of municipal services was significantly influenced by 3 predictor variables. These predictor variables were: failure of municipal employees to talk to residents about payment of municipal services, culture of non-payment of municipal services, and the perception that payment of municipal services was not important, in a decreasing order of strength.

Based on results obtained from personal observation and discussions held with ordinary residents and municipal employees and officials showed that the non-payment of municipal services was caused and aggravated by the following underlying causes:

- Lack of awareness campaigns to have residents educated about the merits of paying for municipal services;

- The wrong perception that the cost of municipal services was unaffordable;

- The wrong assumption that monies paid for municipal services were not used for the benefit of the municipality;

- The perception that municipal officials did not care about the plight of residents and ratepayers;

- Lack of ownership of the municipality;

- Lack of confidence in the ability of municipal employees and officials to improve the plight of residents and ratepayers;

- Inability to pay for municipal services due to joblessness and lack of steady income; and

- Poor motivation. 
The study has shown that ratepayers and ordinary residents could easily develop the perception that elected officials and municipal employees are unable to provide them with quality services due to various reasons. These perceptions and assumptions are often perpetrated by lack of awareness campaigns and visibility by municipal officials. Awareness campaigns are quite helpful in addressing the concerns of ratepayers and residents about the quality of service delivery. Adherence to Batho-Pele Principles and adherence to good governance principles is quite helpful for improving the perception of residents, ratepayers and consumers. Bad experience at municipalities often leads to lack of trust and confidence. Quality control mechanisms should be put in place in order to win the trust of ratepayers and residents.

The study has shown that defaulters believe that they do not have to pay for municipal services that lack quality. This implies that employees must have the commitment and ability to resolve queries promptly and accurately. Customers expect to be able to have access to municipal employees at any time by phone, online or face-to-face. Customers expect complete, prompt and factually accurate answers to their questions and queries. In cases where municipal employees and officials fail to live up to the expectation of residents and ratepayers, customers lose their confidence and trust in municipal employees and elected officials. Scientifically, such problems could be addressed adequately by implementing a suitable monitoring and evaluation programme of action.

The study shown that the non-payment of municipal services was significantly influenced by the failure of municipal employees to talk to residents about payment of municipal services, a deeply entrenched culture of nonpayment for municipal services, and the perception that the payment of municipal services was not important. One of the key findings of study was that defaulters had wrong expectations about municipal services and entitlements. Awareness campaigns are quite helpful in such cases. Municipal employees and officials must be active and visible in the eyes of residents and ratepayers.

The research has shown that the perception and expectation of respondents on the quality of municipal services that were provided to them were significantly influenced by the degree of motivation of employees of Sekhukhune District Municipality at work, the ability of employees of Sekhukhune District Municipality to treat all customers with respect, the ability of employees of Sekhukhune District Municipality to provide adequate answers promptly to queries raised by customers, and the degree to which employees of Sekhukhune District Municipality were skilled on technical issues. Residents, ratepayers and business operators in Tshwane District and Madibeng Municipalities stand to benefit from the provision of workplace career-related training opportunities to employees of Sekhukhune District Municipality. The respondents who took part in the study have emphasized that adherence to Batho-Pele Principles is a key factor that affects their view and perception about the quality of municipal services that are provided to customers. The ideal way in which employees can be motivated at work is the provision of workplace training opportunities in areas that are related to key performance areas and key performance indicators. According to Kotler and Keller (2009), Tshwane District and Madibeng Municipalities must fulfil the expectations and business needs of small businesses operating in the various parts of the town as a means of growing its economy on a sustainable basis. The study conducted by Gertler, Martinez, Premland, Rawlings and Vermeersch (2016) shows that performance monitoring and evaluation plans must be implemented with enough discipline and commitment. Employees must be able to learn from their past mistakes. Norms and standards approved by the South African Government for municipal service delivery must be adhered to by all employees of Sekhukhune District Municipality. Employees who do not have enough motivation and discipline must be encouraged to get professional help and workplace training. In some cases, employees must be educated on ethical principles and the principles of good governance (Too \& Weaver, 2014: 1382-1394).

The benefit of adhering to approved plans of action has been highlighted by Kovacevic (2012: 12-15). Employees must be motivated enough to respect approved plans of action in the course of service delivery. According to the study conducted by Linna, Pekkola, Ukko and Melkas (2010: 300-320), the provision of incentives to star performers is good practice. In order for residents and ratepayers to benefit from municipal service delivery, it is necessary to draw up efficient and feasible business plans for all key operational tasks. Promotions must be based on performance and productivity. Resources that belong to municipalities must be utilized appropriately, and based on approved plans of actions. Incentives must be provided in various forms to employees and officials who perform better than others. Likewise, employees and officials who fail to perform adequately must be provided with 
specialized professional help such as counselling. If that does not help, they should be punished or replaced by others.

In developing municipalities, the key barrier to sustained growth and development is inability to enforce municipal bylaws (Pooe, Worku \& Van Rooyen, 2016). Residents and ratepayers who live and work in Tshwane District and Madibeng Municipalities expect quality services from elected municipal officials and employees. Public service delivery should be a calling to elected municipal officials. However, there is no performance monitoring and evaluation system that could motivate employees to work harder or be innovative. As a result, there are often protests over poor service delivery in most townships (Pooe, Worku \& Van Rooyen, 2016; Khale, 2015; Marivate, 2014; Khale \& Worku, 2013). According to the authors, the most pressing needs of the municipality are related to specialised skills, manpower, budget and infrastructure. Employees working in the municipality need tailor-made skills based training opportunities for improving their current degree of productivity. A review of the literature shows that the provision of skills based training opportunities is a proven method of having employees motivated and committed to duty.

Municipal employees are under attack for poor performance and intolerable conduct (Phago, 2009; Snyman \& Vorster, 2011; Worku, 2013, 2014, 2015, 2016). For instance, some employees in municipalities are not suitably qualified to discharge duties to satisfactory levels (Phago, 2009; Aigbavboa \& Thwala, 2013). Concurring with the latter authors, Alexander (2010) identifies the causes of the dire performance of municipalities as widespread corruption, nepotism and deployment of party 'comrades' to strategic posts in local government structures for which they are unqualified. In light of these few causes of low performance, the provision of training and development is one solution towards the efficient and reliable provision of services to the public (Khale, 2015). Studies conducted by researchers such as Khale (2015), Marivate (2014) and Seeletse (2012) have shown that it is necessary to use measurable and verifiable performance and service delivery targets to local municipalities as a means of avoiding protests over poor service delivery. The author has recommended the provision of workplace training programmes for improving morale and service excellence. A similar assessment has been made by Edoho (2015).

Employee training and development has become one of the key aspects in improving employee performance in organizations, thus leading to improved organisational performance and growth. Aguinis and Kraiger (2009) highlight the importance of employee training and development and the resultant benefits for the organisation when they note that, in future, organisations will depend on well-trained employees who will perform tasks and successfully operate in the global environment. Khale (2015) adds that when organizations offer inducements in the form of developmental opportunities such as training for their current or future roles, employees become motivated to expend their efforts to benefit the organisation.

The King IV Report (Too \& Weaver, 2014: 1382-1394) recommends that municipalities must value and respect service level agreements with ratepayers, stakeholders and the general public. The report shows that there is a significant association between the quality of service delivery to customers and institutional credibility. The report outlines obligations of corporations, companies and institutions in terms of measurable and verifiable service delivery agreements. The management of relationships with stakeholders has been given an extended coverage. Emphasis is placed on business ethics, integrity, honesty and complete transparency in the King IV Report. The report calls for respect for the needs of society and respect for the environment. This multi-disciplinary approach to the management of stakeholder relationships is more realistic and beneficial to companies. One can regard this added area as being a reflection of the actual requirements for ensuring the interest of shareholders, stakeholders, members of society, and that of the environment. The emphasis placed on business ethics and integrity is immense. Thus, the King IV Report fundamentally elevates the requirement for leading organisations from satisfactory performance to the ability to look after the interests of shareholders and other members of society. The take home message from the King IV Report is that corporations must not be allowed to do business and make profit unless otherwise they are equally committed to being honest and looking after the interest of the broader society and the environment we live in.

The King IV Report is locally and globally widely acknowledged as the key guideline for good corporate governance. The document outlines the merit of adhering to principles of objectivity, fairness, accountability and transparency. The document is quite suitable for all South African local municipalities. The document is viewed as 
one of the best guidelines for local and international best practice in public and private practice. According to Southall (2014:48-69), adherence to the King IV codes of good corporate governance is a requirement for alleviating the chronic causes of poor municipal service delivery, corruption and the abuse of public resources. Norms and standards that govern the quality of municipal services in South Africa have been stipulated by the South African Government (Khale, 2015). The norms and standards issued by the South African Government clearly define what constitutes adequate service delivery by municipalities and local governments, and encourage municipalities and local governments to promote the practice of accountability, transparency, objectivity and fairness to all people. The task of verifying quality assurance is a management task that must be handled by independent and suitably qualified bodies as a means of ensuring fairness and objectivity. In this regard, municipalities are encouraged to make decisions based on merits and past track records as a means of ensuring value for money. In the modern and contemporary context, issues such as culture and leadership must be recognized as an important aspect when dealing with quality assurance. It is strategically important for municipalities such as Tshwane District and Madibeng Municipalities to follow municipal development models that have been tried and tested by similar municipalities in other parts of South Africa and the world. In the case of South Africa, the models to be emulated should be those that have been used successfully for the provision of efficient municipal services. According to findings obtained from studies conducted by Brownson (2014) and Shree \& Urban (2012), it is vital for developing municipalities to take valuable lessons locally and globally. Locally, the City of Cape Town serves as a good example. Globally, Cities such as New York, London, Amsterdam, Berlin, Seoul, Tokyo and Beijing serve as good examples. It is strategically beneficial to follow the global trends and challenges in meeting service-related requirements of ordinary residents in the world's largest and most complex municipalities. Service quality is a phenomenon that is dynamic, and changes with time in various communities. The needs and aspirations of residents of the Tshwane District and Madibeng Municipalities can only be met adequately if the Tshwane District and Madibeng Municipalities takes up valuable lessons on efficient service delivery from municipalities that have done relatively better in the past several years. According to the Batho-Pele Principle, residents have the right to protection in emergency situations, as well as the right to relevant information and efficient service delivery.

The study has found that the current quality of municipal services provided to residents of Sekhukhune is fairly satisfactory. It follows that the Tshwane District and Madibeng Municipalities should maintain the current quality of services in the years ahead. This could be done by investing on the training and developmental needs of employees who are responsible for providing routine municipal services to residents, ratepayers and stakeholders in the various parts of the Sekhukhune District Municipality.

\section{RECOMMENDATION}

Based on findings obtained from the study, the following recommendations are made to the Sekhukhune District Municipality with a view to maintain and improve the current quality of municipal services that are provided to residents, ratepayers and businesses that operate in the various parts of the Sekhukhune District Municipality:

It would be helpful for the Tshwane District and Madibeng Municipalities to conduct awareness programmes about municipal services that are offered in the various parts of the Tshwane District and Madibeng Municipalities in order to enable the local community to have a better understanding about routine services that are provided by municipal service providers and officials of the Sekhukhune District Municipality.

It would be beneficial for the Tshwane District and Madibeng Municipalities to maintain the current quality of municipal services in the next decade. To this end, senior employees of the Tshwane District and Madibeng Municipalities should be encouraged to mentor young and newly recruited employees with a view to transfer their valuable skills and operational expertise in the management of municipal services.

It would be valuable to provide incentives to current employees in the form of tailor-made professional development training programmes so that they maintain and improve their current degree of commitment to their daily duties and responsibilities. Relevant incentives would be the provision of tailor-made training and skills development opportunities on a regular basis. 
Staff exchange programmes to other municipalities locally and internationally would enable employees of the Tshwane District and Madibeng Municipalities to share valuable skills and expertise with fellow professionals, thereby allowing them to make valuable contribution to their field of expertise. Assessment of competence should be conducted by the Tshwane District and Madibeng Municipalities on a regular basis as a means of encouraging employees to keep improving their suitability for the job that they are performing at the moment. Operational guidelines should be brought up to better level and quality by local and international standards.

Exceptional leadership qualities and outstanding achievement by ordinary employees of the Tshwane District and Madibeng Municipalities should be acknowledged and rewarded by the Tshwane District and Madibeng Municipalities as a means of up keeping morale and commitment by employees and team leaders. This recommendation is consistent with global best practice in the field of duty.

Emphasis should be placed on Batho-Pele Principles so that service providers and employees show due respect and consideration to each resident, ratepayer and customer who seeks assistance from the Sekhukhune District Municipality. Rewards must be given to best performers in this regard.

\section{AUTHOR BIOGRAPHY}

Professor Zeleke Worku is a South African academic working at the Business School of Tshwane University of Technology (TUT) in Pretoria, South Africa. He holds a Ph.D. in statistics (University of the Orange Free State in Bloemfontein, South Africa) and a second Ph.D. in sociology (Aalborg University, Denmark). Professor Worku's key research interests are in small businesses, project management, service delivery, econometrics, monitoring and evaluation, statistical data mining, biostatistics, epidemiology and public health. Before he joined TUT Business School, Professor Worku has worked at the University of Natal in Durban (1998 to 1999), Vista University in Pretoria (2000), University of Pretoria (2001 to 2007), and University of South Africa (2008 to 2009). Professor Worku lives and works in Pretoria with his wife and two children.

\section{REFERENCES}

Aguinis, H. \& Kraiger, K. (2009). Benefits of training and development for individuals and teams, organizations, and society. Annual review of psychology, 60, 451-474.

Aigbavboa, C. \& Thwala, W. (2013). A Theoretical Framework of Users' Satisfaction/Dissatisfaction Theories and Models. In 2nd International Conference on Arts, Behavioral Sciences and Economics Issues (ICABSEI'2013) Dec (17-18).

Alexander, P. (2010). Rebellion of the poor: South Africa's service delivery protests-a preliminary analysis. Review of African Political Economy, 37(123), 25-40.

Asah, F., Fatoki, O. O. \& Rungani, E. (2015). The impact of motivations, personal values and management skills on the performance of SMEs in South Africa. African Journal of Economic and Management Studies, 6(3), 308-322.

Auditor-General. (2016). Audit report on municipal service delivery for the financial year 2014/2015. [Online]. Available from http://hsf.org.za/ [Accessed: 27 December 2017].

Benjamin, G., Andreas, B. \& Ramon, K. (2012). Organization from a systemic perspective: Application of the viable system model to the Swiss Youth Hostel Association. Kybernetes, 39(9-10), 1627-1644.

Bergman, B. \& Klefsjo, B. (2003). Quality from customer needs to customer satisfaction. 2nd ed. Lund: Studentlitteratur.

Brinkerhoff, D. W. \& Brinkerhoff, J. M. (2015). Public sector management reform in developing countries: Perspectives beyond NPM orthodoxy. Public Administration and Development, 35(4), 222-237.

Bezuidenhout A. \& Nenungwi, A. L. (2012). A competency framework for the small business sector in Johannesburg, South Africa. African Journal of Business Management, 6(47), 11658-11669.

Booysens, I. (2011). Are small, medium- and micro-sized enterprises engines of innovation? The reality in South Africa. Science and Public Policy, 38(1), 67-78.

Browne, W. J. \& Goldstein, H. (2010). MCMC sampling for a multilevel model with non-independent residuals within and between cluster units. Journal of Educational and Behavioural Statistics, 35(1), 453-473.

Brownson, C. D. (2014). Does constituent of entrepreneurial culture differ in individuals? International Journal of Small Business and Entrepreneurship Research, 2(2), 22-27.

Cairns, J. I. \& Sears, A. (2012). The democratic imagination: Envisioning popular power in the twenty-first century. Toronto: University of Toronto Press.

Calvin, J. (2012). Commentary on Isaiah. New York: Ravenio Books.

Culkin, N. \& Mallick, S. (2011). Producing work-ready graduates: The role of the entrepreneurial university. International Journal of Market Research, 53(3), 347-368. 
Dawson, A. (2010). A case study of impact measurement in a third sector umbrella organisation. International Journal of Productivity and Performance Management, 59(6), 519-533.

Diedericks, D. R. \& Joubert, J. W. (2006). Towards transportation system integration in the City of Tshwane Metropolitan Municipality. WIT Transactions on the Built Environment, 89.

Edoho, F. M. (2015). Entrepreneurialism: Africa in transition. African Journal of Economic and Management Studies, 6(2), 127147.

Gerdin, J. \& Greve, J. (2004). Forms of contingency fit in management accounting research-a critical review. Accounting, Organizations and Society, 29(3), 303-326.

Gertler, P.J., Martinez, S., Premand, P., Rawlings, L.B. \& Vermeersch, C.M. (2016). Impact evaluation in practice. Washington D. C.: World Bank Publications.

Hair, J. F., Black, W. C., Babin, B. J. \& Anderson, R. E. (2010). Multivariate data analysis: A global perspective. London: Pearson.

Heck, R.H. \& Thomas, S.L. (2015). An Introduction to Multilevel Modelling Techniques: MLM and SEM Approaches Using Mplus. New York: Routledge.

Henrekson, M. (2014). Entrepreneurship, innovation, and human flourishing. Small Business Economics, 43(3), 511-528.

Horn, A. (2010). Telling stories-a history of growth management in the Gauteng Province (South Africa). European Spatial Research and Policy, 17(2), 41-54.

Hosmer, D. W. \& Lemeshow, S. (2013). Applied Logistic Regression Analysis. New York: John Wiley \& Sons.

Jääskeläinen, A., Laihonen, H., Lönnqvist, A., Palvalin, M., Sillanpää, V., Pekkola, S. \& Ukko, J. (2012). A contingency approach to performance measurement in service operations. Measuring Business Excellence, 16(1), 43-52.

Khale, S. (2015). Assessment of the quality of municipal services in the city of Tshwane, South Africa. Journal of Corporate Governance and Control, 13(1), 678-695.

Khale, S. \& Worku, Z. (2013). Factors that affect municipal service delivery in Gauteng and North West Provinces of South Africa. African Journal of Science, Technology, Innovation and Development, 2(3), 61-70.

Khale, S. \& Worku, Z. (2015). Benefits of good corporate governance principles: A study of the city of Tshwane, South Africa. Journal of Corporate Governance and Control, 13(1), 753-770.

Kleinbaum, D., Kupper, L., Nizam, A. \& Rosenberg, E. (2013). Applied regression analysis and other multivariable methods. New York: Nelson Education.

Kotler, P. \& Keller, K.L. (2009). Dirección de Marketing. London: Pearson Education.

Kovacevic, N. (2012). Righting wrongs: Affirmative action in South Africa. Harvard International Review, 6(1),12-15.

Ladzani, W. M. \& Netswera, G. F. (2009). Support for rural Small Businesses in Tshwane, South Africa. Development Southern Africa, 26(2), 14-21.

Linna, P. Pekkola., S. Ukko, J. \& Melkas, H. (2010). Defining and measuring productivity in the public sector: Managerial perceptions. International Journal of Public Sector Management, 23(3), 300-320.

Marivate, S. P. (2014). The impact of entrepreneurial skills on the viability and long-term survival of small businesses: a case of the city of Tshwane, South Africa. European Journal of Business, Economics and Accountancy, 2(2), 53-72.

Perego, P. \& Hartmann, F. (2009). Aligning performance measurement system with strategy: The case of environmental strategy. Journal of Accounting, Finance and Business Studies, 45(4), 397-428.

Peng, T .J. A., Pike, S. \& Roos, G. (2007). Intellectual capital and performance indicators: Taiwanese healthcare sector. Journal of Intellectual Capital, 8(3), 538-556.

Phago, K. (2009). Integrated Development Plan (IDP) in South African local government: The case of the Sekhukhune District Municipality Metropolitan Municipality. Journal of Public Administration, 44(3), 483-491.

Pla-Barber, J. \& Ghauri, P.N. (2012). Internationalization of service industry firms: understanding distinctive characteristics. The Service Industries Journal, 32(7), 1007-1010.

Pooe, S., Worku, Z. \& Van Rooyen, E. J. (2016). The impact of tailor-made skills based training programmes on the performance of municipalities: The case of the city of Tshwane. Journal of Risk Governance \& Control: Financial Markets and Institutions, 6(4), 24-30.

Shree, S. \& Urban, B. (2012). Internationalisation of South African SMEs: The role of capital factors. Acta Commercii, 12(1), 186-199.

Seeletse, S. M. (2012). Common causes of small businesses failure in the townships of West Rand district municipality in the Gauteng Province of South Africa. African Journal of Business Management, 6(44), 10994-11002.

Sekhukhune District Municipality. (2016). Annual report on the Tshwane District and Madibeng Municipalities for 2013/2014. Polokwane: Gauteng Provincial Government.

Snyman, J. \& Vorster, K. (2011). Towards zero waste: A case study in the city of Tshwane. Waste Management \& Research, 29(5), 512-520.

Southall, R. (2014). Democracy at Risk? Politics and Governance under the ANC. The ANNALS of the American Academy of Political and Social Science, 652(1), 48-69.

South African Auditor-General. (2016). Annual Report for the financial year 2014/2015. [Online]. Available from: http://www.df.gov.za/reports/index.asp [Accessed: 27 December 2017]. 
South African Government Communication and Information System. (1996). Constitution of the Republic of South Africa: Act No. 108 of 1996. [Online]. Available from: www.info.gov.za/documents/constitution/1996/a108-96.pdf [Accessed: 27 December 2017].

South African Government Communication and Information System. (2004). The Municipal Finance Management Act Number 56 of 2003. [Online]. Available from: http://www.info.gov.za/acts/2003/a56-03/index.html [Accessed: 27 December 2017].

South African Government Communication and Information System. (2004). The Municipal System Act Number 32 of 2000. [Online]. Available from: http://www.info.gov.za/acts/2000/a32-00/index.html [Accessed: 27 December 2017].

South African Government Communication and Information System. (2000). Municipal Systems Act of 2000: Act No. 32 of 2000. [Online]. Available From: www.Info.Gov.Za/Documents/Constitution/1996/A108-96.Pdf [Accessed: 27 December 2017].

South African Government Communication and Information System. (2003). Local Government Municipal Financial Act of 2000. [Online]. Available from: www.info.gov.za/documents/2003 [Accessed: 27 December 2017].

South African National Department of Corporate Governance and Traditional Affairs. (2009). Speech by Sicelo Shiceka: Minister of Corporate Governance and Traditional Affairs. [Online]. Available from: http://www.cogta.gov.za/index.php/ [Accessed: 27 December 2017].

South African National Department of Planning, Monitoring and Evaluation. (2016). Operation PHAKISA. [Online]. Available from: www.operationphakisa.gov.za/ [Accessed: 27 December 2017].

South African National Department of Public Service and Administration. (2016). Batho Pele principles. [Online]. Available from: http://www.dpsa.gov.za/batho-pele/index.asp [Accessed: 27 December 2017].

South African National Treasury. (2003). Public Finance Management Act of 2003. [Online]. Available from: www.treasury.gov.za/legislation/pfma/act.pdf [Accessed: 27 December 2017].

South African Parliament. (2015). Accelerating service delivery and addressing challenges through effective cooperative governance [Online]. Available from: www.parliament.gov.za [Accessed: 27 December 2017].

South African Parliament. (2016). NCOP debates provincial week report. [Online]. Available from: http://www.parliament.gov.za/live/ [Accessed: 27 December 2017].

Stata Corporation. (2017). User's guide for STATA version 15. College Station, Texas: STATA Corporation.

Statistics South Africa. (2012). Results of Census 2011. [Online]. Available from: www.statssa.gov.za [Accessed: 27 December 2017].

Too, E.G. \& Weaver, P. (2014). The management of project management: A conceptual framework for project governance. International Journal of Project Management, 32(8), 1382-1394.

Worku, Z. (2013). Analysis of factors that affect the long-term survival of small businesses in Pretoria, South Africa. Journal of Data Analysis and Information Processing, 1(1), 110-129.

Worku, Z. (2014). Differential factors of long-term survival in small and medium-sized business enterprises in Pretoria, South Africa. Journal of Business and Economics, 5(11), 2091-2104.

Worku, Z. (2015). Barriers to the development of entrepreneurial activities in newly established small, micro and medium-sized enterprises in Tshwane. Journal of Corporate Ownership and Control, 3(12), 332-340.

Worku, Z. (2016). The impact of poor quality municipal services on small enterprises. Investment Management \& Financial Innovations, 14(4), 274-279.

World Bank. (2016). World development report: making services work for poor people. Washington DC: World Bank. 